\title{
Some Europeans are more equal than others
}

\author{
Helen O'Nions* \\ Nottingham Trent University
}

\begin{abstract}
The position of Roma migrants in the EU presents an anomaly which challenges the foundations of European Union law. As Union citizens, European migrants are entitled to freedom of movement and residence in Member-States. Yet the rights intended to secure this position have been routinely and selectively denied to Roma migrants, leading to forced evictions and collective expulsions without regard to European Law.
\end{abstract}

As has been evidenced in the UK, Roma arrivals are viewed with particularly acute suspicion; a response which reflects their double-stigmatization as both immigrant and Roma.

At the same time, Roma migration from new Member States has exposed a contradiction inherent in the citizenship project which strikes at the heart of the Union's human rights credentials. The degree of exclusion and inequality faced by Europe's largest minority in all Member States is the most pressing internal human rights issue facing the EU. Yet the European institutions continue to lack a coherent response and defined strategy.

The current European framework demanding National Action Plans is commendable in that it prevents individual states from abdicating responsibility for the situation of their Roma citizens. Nevertheless, the absence of clear targets, Roma engagement and European leadership, suggest that this strategy is doomed to failure - offering little more than a distraction. In a Union predicated on, inter alia, the rule of law, respect for human rights and the protection of minorities, this detached position undermines the legitimacy of the entire citizenship project.

Keywords: citizenship, migration, Roma, exclusion, European Union.

\section{Introduction}

According to the Treaty on the European Union, the Union is founded on the values of respect for human dignity, freedom, democracy, equality, the rule of law and respect for human rights, including the rights of persons belonging to minorities (my emphasis) (EU, 2010a: Art 2). Yet in 2002 Europe's largest minority were described as living in an 'apartheid situation', which found them excluded from virtually every right set down in the EU's Charter of Fundamental rights (EU, 2002: 176). Since the accession of 
thirteen new states, the EU's Roma population has doubled in size to around ten million (European Parliament, 2008; Guild and Cahn, 2008). For well-documented reasons, this figure is subject to much dispute and official data is almost certainly an under-estimate. ${ }^{1}$ But the quest for precise data has too easily become a diversion, conveniently placing a smokescreen over the evidence. If anything, the degree of social exclusion faced by Europe's Roma appears to have increased over the past decade; it has certainly become more visible (Council of Europe, 2010). In lamenting the lack of progress since the European Commission announced national Roma integration strategies, the European Parliament recently noted that "poverty and social exclusion among many Roma have reached a critical level” (European Parliament, 2013: para C).

This paper examines European citizenship rules and their application to Roma migrants from new EU Member States. In so doing it will juxtapose EU law and policy with the realities of Member State actions at the national level, exposing a number of contradictions at the heart of the European citizenship project. Roma migration has resulted in demographic changes in Roma/Gypsy/Sinti communities in old European states, contributing to the identification of the Roma situation as a European concern (Sigona and Vermeersch, 2012; Guy, 2013: 138).

The analysis will reveal how the notion of the European Union as the embodiment of democratic principles and equality, is a myth. As a supra-national behemoth the EU should be able to stand apart from national interests but it has struggled to present a coherent approach to Roma inclusion, preferring subsidiarity and deference to leadership. This approach is compromised as national immigration policies have been forced to adapt to enable the free movement rights of all European citizens (EU, 2010b: Art 20). In many receiving states this new migration has fuelled public anxieties, encouraging the renaissance of the far-right (this can be seen clearly in the rising popularity of right wing, anti-immigration parties in France, Netherlands, Hungary, Greece and the UK). Free movement rights have undoubtedly contributed to the emergence of immigration as the hot political issue in many states, with politicians keen to emphasise the impact on the native labour force, on welfare budgets and on the national culture (Birrell, 2013). Consequently, it is argued that the response to Roma migrants cannot be separated from both European and national immigration politics. Further, it cannot be separated from existing prejudices and fears relating to native Gypsy/traveller populations; the Roma thus find themselves doubly stigmatized as both Roma and migrant (Council of Europe, 2012: 13).

\section{Rights of Union Citizens}

Article 20 of the Treaty on the Functioning of the EU provides that all nationals of Member States shall be afforded citizenship of the Union in addition to their national citizenship (EU, 2010b). Secondary legislation sets out the obligations on Member States who are tasked with enabling this right (EU, 2004). This initially confers a right of movement and residence in other Member States without formalities for three months (EU, 2004: Art 6). Beyond this period there is a presumption that the migrant is economically active or at least self-sufficient (EU, 2004: Art.7). However, a failure to comply with Article 7 does not mean that migrants can be easily expelled. Those who are looking for work cannot be expelled if they are continuing to seek employment and have a 'genuine chance of being engaged' (EU, 2004: Art 14(4)). Further, the rules on expulsion are narrowly construed such that an EU migrant cannot be removed unless on grounds of public policy, security or health (EU, 2004: Art 27). Any removal needs to be proportionate and predicated on an individual assessment of risk to the national interest. This most certainly would not be substantiated by an action such as 
congregating on a street corner, visiting betting shops or failing to dispose of rubbish (Pidd, 2013).

Collective expulsion is also prohibited by The European Convention on Human Rights which requires an individual assessment of circumstances prior any removal action (Čonka v Belgium, 2002). The Council of Europe has ruled that "humanitarian payments' given to migrants by French authorities as a means of securing removal violated the European Social Charter. Individual circumstances had not been examined prior to removal and the payments could not be considered to be truly voluntary as expulsion was probable whether the payment was accepted or not (COHRE v France, 2010).

Economic factors cannot by themselves substantiate a justification for expulsion neither can they provide a basis for discriminatory treatment. The Court of Justice of the EU (CJEU) has repeatedly held that it is discriminatory treatment contrary to European law to deny state support to European citizens, although these cases have centred on questions of temporary support which may facilitate access to the labour market (CJEU Grzelczyk). The Citizenship Directive does not appear to confer a specific right on the migrant to access state benefits, yet the principle of equal treatment in the Treaty has been interpreted in such a way as to allow access to benefits for a homeless EU migrant who could show a period of lawful entry and residence (CJEU Trojani: EU, 2010b: Art 18). The position from the case-law is clear: EU citizens who lawfully exercise their free movement (and are thus not a threat to public security, policy or health) have a right based on the principle of equal treatment to obtain support from the state on the same terms as nationals.

Transposition of the Citizenship Directive into national law has been unusually problematic. Four years after its enactment, the Commission was forced to concede that no provision had been correctly transposed by all Member States (European Commission, 2008). Twelve states had incorrectly or ambiguously transposed the rules on sufficient resources and there was considerable inconsistency in the way that the provisions were applied in practice. The Commission has emphasised that there is no fixed amount that constitutes sufficient resources and that any refusal of a right of residence needs to be taken on the basis of proportionality, necessitating a consideration of the duration of the benefit, the individual's circumstances and the amount involved (European Commission, 2009: 8-9; Carrera, Faure Atger, 2009).

Nevertheless this variable state practice can understandably lead migrants to fear the consequences of requesting state support. The Commission recognises that 'staying under the radar' becomes a sensible survival strategy: "whoever is able to survive by begging, is able to sleep in the streets and is able to live without medical care, does not become a burden to the social assistance system" (European Commission, 2009: 42). Fearing expulsion, migrants may thus become more visible as a problematized group. This can be seen in news reports of overcrowded accommodation, insanitary conditions, homelessness and begging (e.g. Pidd, 2013; Gye, 2013; Shipman, 2013).

\section{Reasons for Roma Migration}

Free movement rights have led to the migration of an estimated fourteen million EU citizens (European Commission, 2013). The number of Roma who have exercised this right is unclear and patterns of such migration are complex (Brown, 2013). However, it is indisputable that Roma migration has attracted a disproportionate amount of negative attention, including targeted measures of expulsion in direct contravention of European law. Interviews with Roma migrants indicate that the common push factors 


\section{p. 7. Some Europeans Are More Equal Than Others}

are poverty and discrimination in home countries. Contrary to the picture painted in some sections of the media, most express a desire to escape poverty through employment and self-sufficiency rather than reliance on welfare (European Commission, 2009; European Dialogue, 2009). The desire for formal employment is the key pull factor (EU FRA, 2009: 45). However this wish is often thwarted by the absence of appropriate skills which can leave Roma migrants dependant on activities in the grey economy (such as begging and selling flowers) or reliant on state welfare (Braham and Braham, 2003: 49). This creates a position of vulnerability which can be exploited by unscrupulous employers and it presents a particular challenge for integration. As a result Roma arrivals may appear more visible than other migrants, leading politicians and sections of the media to resort to a security discourse commonly heard in immigration politics (Bigo, 2000: 171; Huysmans, 2006).

\section{Responses to Roma migration}

There are a number of lessons to be learned from the expulsion of Roma migrants from several European states. Firstly, the treatment of migrant Roma is not easily distinguishable from the treatment of indigenous Roma, Sinti and other Gypsy- traveller communities. Further that the levels of exclusion found in Central and Eastern Europe are also found in older, wealthier European states with much smaller Roma populations (Aradau, 2009). In terms of EU accession, the extent of Roma migration following enlargement demonstrates the failure of the accession process and Commission monitoring to fully engage with the political criteria, satisfaction of which was intended to be a condition of membership. It appears from the Commission's delayed and cautious response that the number of Roma opting to exercise their new migratory rights came as a surprise to the European institutions. In the absence of a clear Roma strategy the Commission looked on as Member States openly flouted their legal obligations. ${ }^{2}$

Nowhere are these lessons more apparent than in Italy where the destruction of Roma and Sinti encampments and the forcible eviction of camp inhabitants, has been continuing for over a decade. In 2006, the Council of Europe found Italy to be in violation of the right to housing under the European Social Charter (ERRC $v$ Italy). Since that decision international bodies have regularly reported on the dire housing situation of the Italian 'nomads' (Hammarberg, 2008; ECRI, 2005). The inaccurate labelling of Roma and Sinti as 'nomads' has served to disguise racism by stripping camp inhabitants of ethnicity but it has also justified an approach which consigns Roma and Sinti to conditions of practical segregation on the outskirts of urban areas (ECRI, 2005; COHRE v Italy, 2009).

Police complicity in forced evictions and the use of excessive force has been a regular feature and camp residents live in conditions of acute vulnerability (Amnesty International, 2013, 2012; Human Rights First, 2008; COHRE v Italy, 2009). The declaration of a 'nomad emergency' in 2008 was used as a pretext to depart from ordinary legal safeguards, allowing prefects to conduct a census of camp inhabitants (Decree, No 92/2008; Scicluna, 2008; Colacicchi, 2008). The census continued notwithstanding condemnation by the European Parliament, resulting in the closure of numerous illegal settlements and forced evictions (Scicluna, 2008; ERRC, 2008a). Many of the camp inhabitants are thought to lack official documentation leaving them de facto stateless (ECRI, 2005). Nomad plans were subsequently devised for several Italian cities, leading to more forced evictions. While plans provided for the resettlement of some camp residents, many were left homeless (Amnesty International, 2010; ERRC, 2009). The European Roma Rights Centre continues to receive reports of mob violence, evictions and forced dispersal in several Italian cities (ERRC, 2014a). 
Notwithstanding the Citizenship Directive, legislation was introduced enabling the collective expulsion of Roma migrants (Binannchi and Dinmore, 2010). Politicians justified their actions by emphasising the criminality and danger posed by Roma migrants. The effects of a securitised public discourse are known to generate rather than eradicate feelings of public insecurity (Huysmans, 2006), so it is perhaps unsurprising that there was widespread support for forced removal from the Italian public. In one national survey, 92 per cent of respondents expressed a view that Roma exploited minors and made their living from petty crime (Kington, 2008; Istituto, 2008).

Perhaps encouraged by the absence of strong condemnation and enforcement action from the European institutions, the French authorities were soon to follow suit (O'Nions, 2011; Severance, 2010). Following a crackdown on unauthorised encampments, the French government expelled around 1,000 Roma in the summer of 2010 (Severance, 2010). Although attempting to justify the evictions and expulsions as a security measure, a leaked Government circular revealed that Roma camps had been specifically targeted (Le Monde, 2010).

Seeing an opportunity to detract criticism from allegations of corruption and the deepening economic crisis, President Sarkozy cynically grouped together French travellers, Roma migrants and resident foreigners as a matter of public security (Nacu, 2012: 1323). The consequences of such initiatives for migrant and native Roma cannot be understated $(\mathrm{CNCDH}, 2013)$. A recent national survey found increasing public animosity towards Roma who make up around 0.6 per cent of France's population. The vast majority of respondents regarded the Roma as nomads (86 per cent) and thieves (78 per cent) (CNCDH, 2013).

Although the EU lacked a coherent response, the Council of Europe's Committee on Social Rights found evidence of direct discrimination and collective expulsion in violation of the Social Charter (COHRE v France). Unfortunately this decision has had little deterrent effect and subsequent legislation, which pays little regard to European law, makes it easier to expel migrants on the basis of begging, land occupation or repeated short-stays on French territory. Human Rights Watch has analysed 198 orders to quit served on Romanian Roma and found that only two orders contained any evidence that the individual had sought reliance on state benefits (Human Rights Watch, 2011). The expulsions continue to this day (ERRC, 2014b).

Elsewhere there has been notable public anxiety over arrivals from new Member States who are typically depicted as competing for jobs and national resources. An opinion poll in 2009 found that British people were less enthusiastic about the benefits of free movement than nationals of other large European nations (Harris Interactive, 2009). The past decade has seen the arrival of half a million Poles, with Polish becoming the second most widely spoken language. Public attitudes towards the Polish community have been marginally more positive than negative, though concerns are regularly raised over the impact of cheap, skilled labour on the native workforce (Blinder, 2012; the impact has recently found to have been exaggerated by politicians, Travis, 2014).

By contrast the response to Roma migration in the UK has had a different tone which at times echoes that found in the Italian and French media coverage. Although confused, the rhetoric centres on two primary concerns, namely the economic consequences of hosting a largely unskilled migrant population, and the cultural differences of that population (which plays into the securitisation discourse). In practice it is difficult to separate these concerns. Implicit assumptions about economic value and cultural difference often inform immigration policy (Fox et al., 2012: 685). This is illustrated clearly by the highly inflammatory language used by David Blunkett MP who blamed Slovak Roma in Sheffield for "aggravating" the local population through 
antisocial behaviour. If this 'aggravation' were not enough, Blunkett went further still in predicting social unrest and riots (BBC, 2013).

The political rhetoric has been unhelpful and has certainly fed public anxieties. Bosworth and Guild argue that "punitive and fearful rhetoric against migrants" has become a central plank of policy in many countries with the effect that all migrants become viewed with suspicion (Bosworth and Guild, 2008: 714). Reporting on migrants is disproportionately focussed on criminality and Romanian migrants seem to attract more of this 'crime' framing than other migrant communities (this has also been reported in other EU states: BBC, 2009). Generalisations regarding Romanian crime (child trafficking, prostitution and theft) have been a particular feature of tabloid reporting over the past five years (Fox et al., 2012: 687). Roma migrants are not easily distinguishable from Romanian citizens and thus their arrival is closely scrutinised. When this rubs against established anti-Gypsy prejudices, a familiar pattern begins to appear. Numbers are frequently exaggerated (Guy, 2003); behaviour which would otherwise seem normal (such as congregating on street corners) becomes threatening and dangerous. The Roma frame emphasises uncivilised behaviour (Clark and Campbell, 2000: 35) which stands at odds with the civilising credentials of the European citizenship project.

\section{Contradictions of the Citizenship project}

Given the degree of marginalisation experienced by sizable Roma populations in the new Europe and the migration opportunities available following enlargement, it is surprising that greater attention was not paid to these issues during the enlargement process. Prior to accession and the designation that all European Member States were free from persecution, Roma from the Czech Republic, Hungary and Slovakia had claimed asylum in the UK and Canada with varying degrees of success (Tóth, 2013; O'Nions, 2007; Guy, 2003). The discriminatory effects of the Czech Citizenship law which left many Roma de facto stateless had been remedied following sustained international criticism. Yet Roma continued to emigrate, notwithstanding the efforts of British immigration officers stationed at Prague airport with the specific role of preventing their departure $(R \vee 10$ at Prague Airport). Reports from the time indicate that the UK was particularly unwelcome to refugees but the arrival of Roma from Eastern Europe was met with a disproportionate degree of hostility (Clarke and Campbell, 2000; Black, 2001).

The capacity and/or willingness of many states to investigate and prosecute an increasing number of violent attacks on Romani citizens is indicative of entrenched discrimination and governmental complacency that should have been tackled head-on in the accession process. In a bold move, the Copenhagen criteria included 'respect for and protection of minorities' as a political condition to be met by acceding states (Guglielmo and Waters, 2005: 771). Whilst this can be viewed as a new 'EU moral standard' in the field of minority protection (Vermeersch, 2011: 344), it seems likely that the motivation was less about human rights or equality and more about assuaging security concerns over mass migration following accession. Minority protection had certainly not been an EU requirement of established states and it has been suggested that its selective application to accession states illustrated 'cognitive dissonance' which may well have undermined its effectiveness (Guglielmo and Waters, 2005: 774).

The application of the political conditions was certainly inconsistent and fragmented. Significantly, the challenge of social inclusion was omitted from the negotiations (Potůček, 2006) and has only recently emerged as a discernible field of EU policy (Guy, 2009: 37; Vermeersch, 2011: 346). The lack of specificity in the 
political criteria enabled candidate states to engage in 'creative manipulation' to appear compatible with the accession requirements (Fox and Vermeersch, 2010). Yet the evidence of non-compliance was there for those who cared to look (Crowe, 2006). In addition to the well-documented data on social exclusion indicators (which should have suggested deeper, more intractable problems), there are numerous examples of state complicity in rights violations. The European Court of Human Rights has been repeatedly called upon to defend the rights of Roma citizens where the institutions in their country of nationality have neglected to do so. The aftermath of the Hadareni pogrom which resulted in the murder of three Romani villagers and the arson of Romani homes is one such example. Most of the perpetrators were identified and finally convicted in 1998 but the Romanian Supreme Court acquitted two defendants and pardoned the others only two years later. A friendly settlement, which included damages and the introduction of a series of tolerance measures, was reached in Moldovan and Others $v$ Romania but Cahn suggests that the agreed measures have yet to be adequately implemented (Cahn, 2013: 63).

A series of cases illustrate grave failings in the rule of law and the protection of the Roma in Bulgaria. In three separate cases concerning deaths of Roma citizens at the hands of the police, the European Court found breaches of fundamental rights (Anguelova; Assenov and Nachova). In Nachova v Bulgaria two unarmed Romani men had absconded from military service and were subsequently shot and killed by military police. A Bulgarian Court found the killings to be lawful and there were no convictions but the European Court found that this failure to investigate and prosecute the perpetrators constituted a violation of the right to life. Significantly the Court also found a violation of the principle of non-discrimination as investigating officers had failed to examine evidence of racist shouting by an officer at the time of the incident.

Complaints before the Strasbourg Court will inevitably only arise in a small number of cases where the applicant is made aware of their rights and has access to legal advice and support. The facts in these cases are thus unlikely to be isolated incidents. In the case of Horvath $v$ SSHD, the UK House of Lords found the applicant's evidence of persistent discrimination and violent attacks by skinheads in Slovakia to be credible. Mr Horvath's asylum claim was unsuccessful as he was unable to demonstrate a failure of state protection which the Court interpreted narrowly so as to require the applicant to have actively sought protection from the state. By contrast, a failure of state protection was often implied in the decisions of the Canadian Refugee Board. In Harakal v SSHD, the UK Court of Appeal ruled in favour of a Czech Roma asylum seeker who had faced 'significant discrimination in all facets of his life, throughout his life'.

Once the conditions of accession were deemed satisfied the European Commission lost important leverage; there was no longer a political incentive for governments to justify targeted integration measures. Yet there was ample evidence to indicate the extent of Roma segregation prior to enlargement. The key indicators of ghettoization identified in the work of Marcuse and Wacquant include spatial confinement, ethnic homogeneity, shared cultural identity, mutual distancing and a retreat in the private realm of family life (Marcuse, 1997; Wacquant, 2012). Whilst Powell identifies complexities in the application of the ghetto to British Gypsies and Travellers (Powell, 2013), these factors certainly characterise the Roma community in Central and Eastern Europe. Further, a historical analysis which examines the role of the state in maintaining these boundaries helps to explain the degree of structural discrimination encountered by Romani communities in these countries (Powell, 2013: 120).

Roma camps are typically on the outskirts of urban areas and municipal resources are often very limited. This analysis can be seen in France and Italy and also with regard to unauthorised encampments in the UK. But the construction of a ghetto is most clearly exhibited by the physical demarcation of Roma communities through the 
construction of barriers and walls to segregate. In 1998, the authorities in the Czech town of Usti Nad Labem attracted international condemnation after constructing a wall to segregate Romani citizens from their neighbours (The Guardian, 1998: 16). In 2012, the authorities in the Slovakian city of Kosice, latterly awarded the accolade 'European capital of culture', constructed a similar wall to segregate Romani citizens. These were not isolated incidents. The Kosice wall was reportedly the fourteenth of its kind since Slovakian accession to the EU (BBC, 2012).

The point has been made that these are not problems particular to Eastern Europe. In 2000, the High Commissioner on National Minorities reported that all 57 OSCE states had a human rights obligation to take corrective measures to improve the Roma experience (HCNM, 2000: Foreword). More recently, the EU's Fundamental Rights Agency undertook a study of eleven Member States with sizable Romani populations and concluded that, without exception, Roma were worse off than non-Roma citizens in all states surveyed. Significantly, less than 30 per cent of Roma were in paid employment and only 15 per cent of young Roma adults had completed upper secondary or vocational schooling (EU FRA, 2012). The experiences of the Gypsytraveller community in the UK may have little in common with the predominately sedentary Roma populations of Eastern Europe but the indicators of disadvantage are equally strong (Dept for Communities and Local Government, 2012). In a European Union predicated on values of human rights, equality, democracy and the rule of law, these figures are truly shocking.

To go forward the EU has to act in tandem with national governments to seriously tackle the issues facing Europe's Roma. The progress to date on the National Roma Integration Strategies has been far from satisfactory (European Parliament, 2013; EU, 2011). As in Eastern Europe, the British Government has left much of the responsibility for implementation to local councils, charities and community cohesion initiatives (Fletcher, 2013). The UK's action plan pursuant to the Roma Integration Strategy has focussed almost entirely on indigenous travelling people, ignoring a significant number of migrant Roma (European Council, 2012). The Minister for Housing exhibited a degree of indifference and some confusion when emphasising that the UK had comparatively few Roma citizens and would therefore regard the imposition of targets and positive measures as particularly 'burdensome'. The government's principal interest in Roma migration centres on preventing benefit tourism rather than facilitating social inclusion (Vogel, 2013; The Economist, 2014). The perception that Roma migrants constitute a particular burden on the welfare system of host states has been fuelled by comments of the Romanian Prime Minister who has publically stated that benefits tourism is a 'specific situation of the Roma community' (BBC, 2013b).

The EU enlargement process has been conceived as a modernising and civilising project but the Roma have been depicted in public discourse as belonging to a different, primitive world. Simhandl illustrates how the European institutions have continued to fuel this perception in a discourse which perceives Roma as political objects rather than human beings (Simhandl, 2006). Clumsy distinctions are drawn between Eastern Roma and Western Gypsies, between sedentarism and nomadism; masking entrenched discrimination in the older European states.

There are clear inconsistencies in EU policy which need to be remedied if the EU is to have any credibility in overseeing national action plans. Failing to enforce the Citizenship Directive is one example. Another can be seen with respect to the relaxation of the visa regime for nationals from the Western Balkans. The European Commission has reportedly exerted pressure on these states to prevent the departure of asylumseekers which has had a disproportionate effect on Roma, many of whom have left Serbia due to acute discrimination and social exclusion following the dissolution of Yugoslavia (Council of Europe, 2012; ERRC, 2013a). This perhaps demonstrates the 
danger of relying on national mechanisms and suggests a need for greater clarity and purpose at both levels.

Norm diffusion is the most effective strategy for addressing nationalistic and racist prejudice and can pave the way towards Roma social and political citizenship (Allam, 2010; Vermeersch, 2012: 1203). The EU enjoys sources of power and resources which can influence the society of sovereign states to deliver real citizenship to Roma. But the Commission undoubtedly needs to be more effective in promoting social cohesion and tackling discrimination (Guy, 2009). Early indicators from national action plans implemented by the Czech Republic, France and Portugal have not given cause for optimism (ERRC/NÚMENA, 2007). Guy criticises a 'cut and paste' culture which lacks dynamic planning in addition to the age-old problem of translating national strategies into tangible benefits at local level (Guy, 2009: 39). The OSCE has been operating an action plan on improving the situation of Roma and Sinti over the past decade but responses to a periodic review in 2013 found that EU enlargement and the global financial crisis have had a major impact on the situation. Despite some examples of visible progress, social exclusion as a whole appears to have deepened in the 41 respondent states (OSCE, 2013). Data from civil society organisations suggest that incidents of hate crime are increasing and this is likely to continue as politicians and mainstream media continue to focus on Roma criminality. Many states lack specific hate crime legislation and do not collect data on racially motivated crime. This is a field where the EU can and should exert some influence pursuant to the Charter on Fundamental Rights and equal treatment legislation (European Council, 2013).

\section{Conclusion}

It is clear that the integration of migrants presents challenges for host populations and this will be exploited by those keen to exaggerate tensions for their own political agendas. Yet the increased visibility of Roma communities on the streets of 'old' Europe may finally provide the momentum towards an effective European Roma strategy (Vermeersch, 2012: 1196). This strategy demands a holistic approach which focuses on all indicators of disadvantage as well as the structural discrimination which continues to exclude Roma from full participation as European citizens. It is essential that the search for solutions avoids entrenching the position of victim and perpetrator. In this respect caution needs to be exercised when advocating an ethnically predicated Roma politics. Increasingly advocates are also recognising the danger in focusing on an exclusively European solution which can obscure the primary responsibility of national governments (Gheorghe, Kovats in Guy, 2013; Kovats, 2012). The dissemination of a narrative which separates Roma from non-Roma can symbolically exclude them from the national populations in which they live. Further, it is argued that by emphasising a particular form of Roma marginalisation, policy-makers may inadvertently imply that marginality and exclusion are a symptom of Romani identity. Thus "from deprived cocitizens, the Roma are turned into cultural deviants" (Vermeersch, 2012: 1206).

The EU has announced a European Platform against Poverty as part of 'Europe 2020' which promises to address the integration of Roma citizens in the new Europe. Additionally all Member States are required to present action plans as part of the EU Framework for National Roma Integration (European Commission, 2011b; 2012a). These are important new developments which have been catapulted to the fore of EU Justice and Home Affairs policy because older EU states are no longer permitted to side-step the issue as something specific to central and Eastern Europe. Yet there are considerable obstacles which continue to enable governments to deflect criticism towards both new European states and the European Commission. 
The UK's integration strategy demonstrates some of these issues. The two page document submitted to the Commission begins by estimating the Roma population at between 80,000 and 300,000 , a divergence that is difficult to comprehend even taking account of the challenges in accurate data collection (UK Factsheet, 2012). More worrying is the absence of clear financial commitments in meeting any of the objectives identified. The objectives themselves are vague and there is no time-scale identified. In fact only twelve Member States identified any funding for the national strategies (European Commission, 2012b). There appears to be a very long way to go before paper commitments result in significant action in the majority of Member States. In the meantime the practical reality continues to be a very long way from the founding principles of the Union. The destruction of homes and the collective removal of Roma migrants continues openly, challenging the integration agenda (ERRC, 2014).

Whereas the special status of national citizenship is used to define the nation-state, the status and rights commensurate with European citizenship have the potential to legitimise and shore up a political Union of diverse interests. This Union should be based on the transcending values listed in the Treaty of the European Union, including the rule of law, human rights and the protection of minorities. The project however has to be seen as a failure when Europe's largest minority find themselves excluded from full membership. The recent EU Summit has been criticised for perpetuating this exclusion through its top-down approach and lack of engagement with Romani representatives (Kawczynski, 2014). When free movement laws can be openly flouted without consequence and Member States fail to commit sufficient energy and resources to the eradication of discrimination and social exclusion.

\section{Notes}

1 Twenty years ago it was estimated that there were up to three million Roma living in Romania and Slovakia alone (Liegeois and Gheorghe, 1995).

2 With the notable exception of Commissioner Reding who likened the French expulsions to expulsions of the Jews during the Vichy regime: The Week "Expulsion of Roma “bad as Vichy France and Jews” 15.9.2010.

* Correspondence Address: Dr Helen O'Nions, Nottingham Law School, Nottingham Trent University, Burton Street Nottingham NG1 4BU. Email: Helen.O'Nions@ntu.ac.uk

\section{References}

Allam, N. (2010) Stateless Roma in Europe: A case study of European Migration, Citizenship and identity Policies Paper at $8^{\text {th }}$ ECSA-C Biennial conference 'Wither Europe?' Victoria, BC, 30 April 302010.

Amnesty International (2013) Italy: Roma Segregation Camps - A Blight On The City Of Rome. Press Release. London: Amnesty International.

Amnesty International (2012) Annual Report - The State of the World's Human Rights, Italy May 2012. Available at: https://www.ecoi.net/local_link/ 217467/339328_de.html

Amnesty International (2010) The Wrong Answer. Italy's Nomad Plan Violates the Housing Rights of Roma in Rome. London: Amnesty International.

Aradau, C. (2009) The Roma in Italy Racism as Usual? Radical Philosophy, 153, 27. 
BBC (2013a) 'David Blunkett Riot Fear Over Roma Migrant Tensions,' BBC, 12 Nov. Available at: $\quad$ http://www.bbc.co.uk/news/uk-politics-24909979 (Accessed $12 / 2 / 14)$

BBC (2013b) 'Romanian PM: Benefit Tourism is Roma Problem,' BBC, 19 March. Available at: http://www.bbc.co.uk/news/world-europe-21842317

BBC (2012) ‘Slovakia 'Anti-Roma' Wall, In: Kosice Riles EU’, BBC, 2 May 2012.

BBC (2009) 'How Gypsy Gangs Use Child Thieves, BBC, 2 Feb 2009.

Bigo, D. (2000) When Two Become One: Internal and External Securitisations in Europe' In: Kelstrup, MW and Williams, M (eds.) International Relations Theory and the Politics of European Integration: Power, Security and Community. Routledge.

Binannchi, G. and Dinmore, G. (2010) 'Italy Pushes Law Driven By Roma Influx,' Financial Times, 10 September.

Birrell, I. (2013) 'A Queens Speech ruined by Absurd Anti-Immigration Measures,' The Guardian, 8 May.

Black, I. (2001) 'UK 'Most Racist in Europe' on Refugees,' The Guardian, 3 April.

Blinder, S. (2012) UK Public Opinion toward Immigration: Overall Attitudes and Level of Concern. Oxford: Migration Observatory, University of Oxford.

Bosworth, M. and Guild, M. (2008) Governing Through Migration Control: Security and Citizenship in Britain. British Journal of Criminology, 48, 6, 703-719.

Braham, M. and Braham, M. (2003) Romani Migrations and EU Enlargement: Reply to Critics and Some Epistemological Considerations for Policy-Making 31 Nationalities Papers, 1, 47-82.

Brown, P, Scullion, L and Martin, P (2013) Migrant Roma in the United Kingdom. Salford: University of Salford.

Cahn, C. (2013) Roma and Racial Discrimination- The Jurisprudence of the European Court of Human Rights in Bigo, Carrera and Guild (eds.) Foreigners, Refugees of Minorities? Aldershot: Ashgate.

Cahn, C. and Guild, E. (2008) Recent Migration of Roma in Europe OSCE 2nd ed.

Carrera, S. and Faure Atger, A. (2009) Implementation of Directive 2004/38 in the Context of EU Enlargement: A proliferation of Different Forms of Citizenship? CEPS Special Report April 2009.

Clark, C. and Campbell, E. (2000) 'Gypsy Invasion' A critical analysis of newspaper reaction to Czech and Slovak Romani asylum-seekers in Britain 1997. Romani Studies, 10, 1, 23-47.

CNCDH (Commission Nationale Consultive des droits de l'homme) 2013 La Lutte Contre Le Racisme, L'antisémitisme Et La Xénophobie. Available at http://www.west-info.eu/roma-in-france-small-population-big-problem/rapportcncdh-racisme-2013-2/

COHRE (Centre on Housing Rights and Evictions) v France (2011) No. 63/2010 European Committee of Social Rights 28 June 2011, Council of Europe.

COHRE v Italy (2009) No 58/2009 European Committee of Social Rights, $11^{\text {th }}$ June 2009 Case Document No 1, Council of Europe.

Colacicchi, P. (2008) Ethnic Profiling and Discrimination Against Roma In Italy: New Developments in a Deep-Rooted Tradition. Roma Rights Journal 2.

Council of Europe (2012) Parliamentary Assembly Roma Migrants in Europe. Report Doc 129508 June 2012.

Council of Europe (2010) Parliamentary Assembly Resolution 1760 (2010).

Council of Europe (2006) Committee of Ministers Res Chs (2006)4 Collective Complaint No. $27 / 2004$ by the European Roma Rights Centre against Italy.

Crowe, D. (2006) The Roma in Post Communist Eastern Europe: Questions of Ethnic Conflict and Ethnic Peace. Nationalities Papers, 36, 3, 527-541.

Department for Communities and Local Government (2012) Progress Report by the Ministerial Working Group on Tackling Inequalities Experienced by Gypsies and 
Travellers. Available at https://www.gov.uk/government/organisations/ department-for-communities-and-local-government

The Economist (2014) 'The Gate are Open,' The Economist, 14 January.

ECRI (2005) European Commission against Racism and Intolerance Third Report on Italy, 16 Dec 2005. Council of Europe.

European Dialogue (2009) The movement of Roma from new EU Member States: A mapping survey of A2 and A8 Roma in England. London: Department for Children, Schools and Families.

EU (2010a) Treaty on the European Union, 30.3.2010 OJ 83/13.

EU (2010b) Treaty on the Functioning of the European Union, 30.3.2010 0J 83/47

EU (2004) Directive 2004/38/EC Of The European Parliament And Of The Council Of 29 April 2004 On The Right Of Citizens Of The Union And Their Family Members To Move And Reside Freely Within The Territory Of The Member States OJ L258/77 30.4.04

EU (2002) Network of Independent Experts on Fundamental Rights Report on the Situation of Fundamental Rights in the EU and its Member States (EU: Network).

European Commission (2013) Impact of Mobile EU Citizens on National Social Security Systems. Available

at: http://ec.europa.eu/social/main.jsp?langld=en\&catld=89\&newsld=1980\&furthe $\underline{\text { rNews }=\text { yes }}$

European Commission (2012a) Communication from The Commission To The European Parliament, The Council, The European Economic And Social Committee And The Committee Of The Regions National Roma Integration Strategies: A First Step In The Implementation Of The EU Framework, Com/2012/0226 Final.

European Commission (2012b) European Commission Calls On Member States To Implement National Plans For Roma Integration Press Release 23 May.

European Commission (2011a) Communication From The Commission To The European Parliament, The Council, The European Economic And Social Committee And The Committee Of The Regions An EU Framework For National Roma Integration Strategies Up To 2020 Com/2011/0173 Final.

European Commission (2011b) Framework for National Roma Integration Strategies, $5^{\text {th }}$ April $2011 \mathrm{IP} / 11 / 40, \mathrm{MEMO} / 11 / 216$.

European Commission (2009) Communication from the Commission to the European Parliament and the Council on Guidance for better Transposition And Application Of Directive 2004/38/EC On The Right Of Citizens Of The Union And Their Family Members To Move And Reside Freely Within The Territory Of The Member States Brussels COM (2009) 313/4 final 2.7.2009.

European Commission (2008) Report from the Commission to the European Parliament and the Council on the Application of Directive 2004/38 on the Right of Citizens of the Union and their family members to move and reside freely within the Territory of the Member States Brussels COM (2008) 840/3.

European Council (2013) Conclusions On Combating Hate Crime In The European Union Justice and Home Affairs Council Meeting, Brussels 5 and 6 December 2013.

European Council (2012) Conclusions on an EU Framework Strategy for Roma Integration up to 2020: Great Britain and Northern Ireland.

EU FRA (2012) Fundamental Rights Agency The Situation of Roma in 11 EU Member States (EU, FRA).

EU FRA (2009) Fundamental Rights Agency The Situation of Roma EU Citizens Moving to and Settling in Other EU Member States Nov 2009 (EU, FRA).

European Parliament (2013) Motion for a Resolution on the progress made in the implementation of the National Roma Integration Strategies (2013/2924RSP) 6.12.2013. 
European Parliament (2008) Resolution of 23rd Jan 2008 On a European Strategy on the Roma P6_TA (2008) 0035.

ERRC (2014a) European Roma Rights Centre Milan Authorities Continue Evicting Roma News, 13 March 2014.

ERRC (2014b) European Roma Rights Centre News Forced Evictions of Roma Double in France, Vol 22 and 23, December 2013 - March 2014.

ERRC (2013) European Roma Rights Centre (2013a) Written Comments by the European Roma Rights Centre Concerning Serbia. Regarding EU Accession Progress for Consideration by the European Commission During its 2013 Review Available at: http://www.errc.org/cms/upload/file/ec-progress-report-serbia2013.pdf (Accessed 14/2/14)

European Roma Rights Centre et al (2009) Violations of EC Law and the Fundamental Rights of Roma and Sinti by the Italian Government in the Implementation of the Census in "Nomad camps" Memorandum to the European Commission. ECR0902-5-EC Joint Submission-RS-5.4.09.

Fletcher, A. (2013) 'The Report,' BBC Radio 4, 6 December.

Fox, J., Morosanu, L. and Szilassy, E. (2012) The Racialization of the New European Migration to the UK. Sociology, 46, 4, 680-695.

Fox, J. and Vermeersch, P. (2010) Backdoor Nationalism European. Journal of Sociology, 51, 2, 325-357.

Guglielmo, R. and Waters, T.W. (2005) Migrating Towards Minority Status: Shifting European Policy Towards the Roma. JCMS, 43, 4, 763-86.

Guy, W. (ed.) (2013) From Victimhood to Citizenship. Pakiv European Roma Fund.

Guy, W. (2009) EU Initiatives on Roma: Limitations and Way Forward, In: Sigona, N. and Trehan, N. (eds.) Romani Politics in Contemporary Europe .Poverty, Ethnic Mobilization and the Neoliberal Order. Palgrave Macmillan: 23-50.

Guy, W. (2003) No Soft Touch: Romani Migration to the UK at the turn of the TwentyFirst Century. Nationalities Papers, 31, 1, 63-76.

Gye, H. (2013) 'Roma Already In Britain 'Are Defecating On People's Doorsteps' Says Top Tory Council Leader As She Warns Of Burden That Romanian And Bulgarian Immigrants Will Place On Public Services,' Mail Online 31 December.

Hammarberg, T. (2009) Commissioner for Human Rights of the Council of Europe, following his visit to Italy on 13-15 January 2009, CommDH (2009)16 (Strasbourg: Council of Europe, 16th April 2009).

Hammarberg, T. (2008) Memorandum CommDH - 18 by Thomas Hammarberg Commissioner for Human Rights of the Council of Europe.

Harris Interactive (2009) In United States and Largest European Economies Public Opinion Is Split on Issues of Economic Nationalism, Protectionism and Internationalism.

HCNM High Commissioner on National Minorities (2000) Report on the Situation of Roma and Sinti in the OSCE Area.

Human Rights First (2008) Violence Against the Roma. Hate Crime Survey. Available at: https://www.humanrightsfirst.org/wp-content/uploads/pdf/fd-080924-romaweb.pdf

Human Rights Watch (2011) France's compliance with the European Free Movement Directive and the Removal of Ethnic Roma EU Citizens. Briefing Paper to the European Commission, July 2011.

Huysmans, J. (2006) The Politics of Insecurity: Fear, Immigration and Asylum in the EU. London: Routledge.

Istituto per gli Studi sulla Pubblica Opinione. Italiani, Rom e Sinti a confronto: una ricerca qualitativa. Conferenza Europea sulla popolazione Rom. Rome 22-23 January 2008.

Kington, T. (2008) ‘68\% Of Italians Want Roma Expelled - Poll,' The Guardian, 17 May. Kovats, M. (2012) 'The EU's Roma Role,' Open Democracy, 11 May. 
Kawczynski (2014) Open Letter to Ms Reding, Mr Barroso, and Mr Schulz European Roma and Travellers Forum, 3 April 2014.

Le Monde La Circulaire visant les Roms est "tres probablement illegal' 12th Sept. Available at: http://www.lemonde.fr/politique/article/2010/09/12/la-circulairevisant-les-roms-est-elle-llegale_1410188_823448.html

Liegeois, J.P. and Gheorghe, N. (1995) Roma: A Persecuted People. London: Minority Rights Group.

Marcuse, P. (1997) The Enclave, The Citadel, And The Ghetto: What Has Changed In The Post-Fordist US city. Urban Affairs Review, 33, 2, 228-264.

Nacu, A. (2012) From Silent Marginality to Spotlight Scapegoating? A Brief Study of France's Policy Towards the Roma. Journal of Ethnic and Migration Studies, 38, 9, $1323-1328$.

O'Nions, H. (2011) Roma Expulsions and Discrimination: The Elephant in Brussels. European Journal of Migration and Law, 13, 4, 361- 388.

O'Nions, H. (2007) Minority Rights Protection in International Law. The Roma of Europe. Aldershot: Ashgate

OSCE (2013) Implementation of the Action Plan on Improving the Situation of Roma and Sinti Within the OSCE Area Status Report 2013.

Pidd, H. (2013) 'Slovakian Roma in Sheffield: 'This Is A Boiling Pot Ready To Explode", The Guardian, 15 Nov.

Potůček, M. (2006) Does the Lisbon Strategy Matter? The Czech Experience Conference paper for Reforms in Lisbon Strategy Implementation: Economic and Social Dimensions Zagreb, May.

Powell, R. (2013) Loïc Wacquant's 'Ghetto' and Ethnic Minority Segregation In The UK: The Neglected Case of Gypsy-Travellers. International Journal of Urban and Regional Research, 37, 1, 115-34.

Scicluna, H. (2008) The Life And Death Of Roma and Sinti in Italy: A Modern Tragedy. Roma Rights Journal, 2, 2008.

Severance, K. (2010) 'France's Expulsion of Roma Migrants: A test Case for Europe Global Research,' October 22. Available at: http://www.globalresearch.ca/frances-expulsion-of-roma-migrants-a-test-case-for-europe/21558

Shipman, T. (2013) 'Influx of Roma Migrants Could Spark City Riots, Warns David Blunkett,' Mail Online $12^{\text {th }}$ Nov.

Sigona, N. and Vermeersch, P. (2012) The Roma In The New EU: Policies, Frames And Everyday Experiences. Journal of Ethnic and Migration Stud.38, 8, 1189-1193.

Simhandl, K. (2006) 'Western Gypsies and Travellers' - 'Eastern Roma': The Creation of Political Objects by the Institutions of the European Union. Nations and Nationalism, 12, 1, 97-115.

Tóth, J. (2013) Czech And Hungarian Roma Exodus To Canada: How To Distinguish Between Unbearable Destitution And Unbearable Persecution, In: Bigo, Carrera and Guid (eds) Foreigners, Refugees of Minorities? Aldershot: Ashgate 39.

Travis, A. (2014) 'Immigration Report That Challenges Impact On UK Jobs 'Blocked' By No 10,' The Guardian, 5 March.

UK Factsheet (2012) Implementing National Plans for Roma Integration. Available at: http://ec.europa.eu/justice/discrimination/files/country factsheets 2012/unite d-kingdom en.pdf

Vermeersch, P. (2012) Reframing the Roma: EU Initiatives and the Politics of Reinterpretation. Journal of Ethnic and Migration Studies, 38, 8, 1195-1212.

Vermeersch, P. (2011) The European Union and the Roma: An analysis of Recent institutional and Policy Development. European Yearbook of Minority Issues, 10, 341-358.

Vogel, T. (2013) 'Commission and UK at odds over "benefits tourism", European Voice, 17 October. 
Wacquant, L. (2012) A Janus-Faced Institution Of Ethnoracial Closure: A Sociological Specification Of The Ghetto, In: Hutchsinson and Haynes (eds.) The Ghetto: Contemporary Global Issues And Controversies. Westview, Boulder CO.

\section{Cases}

\section{CJEU}

C184/99 Grzelczyk v Centre Public d'aide Sociale d'Ottignies-Louvain-la-Neuve. Available at http://eurlex.europa.eu/LexUriServ/LexUriServ.do?uri=CELEX:61999J0184:EN:HTML

C456/02 Michel Trojani v Centre Public D'aide Sociale De Bruxelles. Available at: http://curia.europa.eu/juris/liste.jsf?language=en\&num=C-456/02

\section{European Court of Human Rights}

Anguelova v Bulgaria App 38361/97 13.09.2002

Assenov v Bulgaria 90/1997/874/1086

Conka v Belgium 51564/99 2002

Nachova and Others v Bulgaria 43577/98 and 43579/98 2005

Velikova v Bulgaria App 41488/98, 18.05.2000

UK

$R$ v 10 at Prague Airport and Another, exp European Roma Rights Centre [2004] UKHL 55ERRC 